\title{
UNIVERSITY RANKING: Criteria of What Makes a Great University
}

\author{
By: Muhamad Wayong*
}

\begin{abstract}
ABSTRAK: The THES mungkin lembaga paling kredibel dalam menetapkan renking perguruan tinggi level internasional. Menurut lembaga ini Amerika Serikat mendominasi peringkat teratas dalam daftar peringkat universitas terbaik dunia. Sebaliknya, perguruan tinggi di negara-negara mayoritas Muslim, termasuk Indonesia, perlu menanti waktu yang amat panjang untuk meraih status universitas bertaraf internasional. Untuk kasus Indonesia, ada beberapa perguruan tinggi negeri yang ternama, namun demikian, dalam dua dekade terakhir perguruan tinggi swasta baru telah menjamur dan menawarkan bukan hanya fasilitas pembelajaran modern, tetapi juga program pendidikan yang lebih holistik. Untuk memilih perguruan tinggi mana yang terbaik, Globe Asia telah menetapkan kriteria yang mencakup tiga kategori pokok: ekselensi akademik, pendidikan holistik dan dinamisme kampus, serta pengaruhnya terhadap masyarakat.
\end{abstract}

KATA KUNCI: University, university ranking, ranking criteria

COMPETITION in the global era is unavoidable, and it is widely accepted that top class universities are of great importance for a nation's economic competitiveness and the breeding ground for its future leaders. The best universities both nationally and internationally, breed innovative thinking and promote good social behaviors. In fact, the alumni of top universities are more likely to develop companies, manage large corporations and lead major social and economic institutions. Also, nearly all presidents and prime ministers in the world are the alumni of distinguished universities of the country. Due to this, striving to become a world class university is

*The author obtained his Ph.D. from the Faculty of Politic and Social Sciences, Flinders University of Australia, focusing on "Academic Leadership and Management of Higher Education". He also got his Masters Degree from the same university of the School of Education, majoring on Educational Management. He is currently teaching at the Faculty of Education and the School of Postgraduate of the Alauddin State Islamic University of Makassar. 
nothing unusual today, and a number of universities determine to create new models of university campuses.

Despite the fact that university ranking system is debatable, some institutions have endeavored to rank the top state and private universities both nationally and internationally using criteria and a ranking system. These focus not just on the curriculum and academic excellence but incorporate the softer elements such as holistic education and campus dynamism as well as the impact to society. A number of universities have undergone some dramatic changes as they strived to meet the demands of the $21^{\text {st }}$ century, and "World Class Universities" becomes the catchword, although not many universities can honestly claim to be in that category. ${ }^{1}$

There are differences that exist between the various universities in formulating the ranking system. Despite this, to be a truly world class university, a university must offer a comprehensive academic program, possess both strong and experienced faculty, have independent stand-alone research departments, offer students a range of experience by having strong student-driven programs, and a conducive and enriching learning environment. Additionally, a university must be comprehensive in both its academic and non-academic fields and its graduates must be highly respected as both professionals in their chosen fields as well as community leaders. They must be highly priced by employers and also by society at large. ${ }^{2}$

This paper deals primarily the ranking system and criteria of top universities both nationally and internationally. Obviously, not everyone will agree with the ranking system and criteria, and it will ignite debate and discussion within the country about what makes a good university. Nevertheless, the ranking system would be a guide to raise the standard of higher education. Secondly, this paper discusses higher education reform in Indonesia with respect to the way to improve the quality of education and include them in list of top class universities both in the national and international level.

\section{RANKING CRITERIA}

At the international level, an assessment of more than 1000 higher education institutions was held by the Times Higher Education Supplement (THES) in the end of 2006. The THES was using five key indicators to select the top 200 universities in the world. The indicators included asking 3700 research-active academics globally to name the top 30 research universities in their field of expertise as well as counting the citations per published paper by researchers at each institution. The other indicators 
were the number of foreign students enrolled, staff-student ratios and top companies' assessment of the quality of an institution's graduates. ${ }^{3}$

The US, with 5 per cent of the world population, had 54, or 27 per cent, of the top 200 universities. Apart from this, The US dominated the top position of the top 200 selected universities. The top 10 universities, for example, included Harvard University, Yale University, Columbia University, California University of Los Angeles, the University of Chicago, etc. The selected top 54 universities of The United States did not even show significant difference in terms of the aforementioned five categories because they are all strong in research, strong in international programs, strong academics, and having good reputation of alumni.

Harvard and Yale university in The United States, for example, are classified the best universities in the world because Harvard graduates are highly priced by private employers, especially Wall Street firms who value Harvard Business school graduate above all other business schools in the country. Yale graduates may not command the same salaries as their friends from Harvard. However, Yale University has a reputation for turning out future American presidents as both Bill Clinton and George W. Bush were the alumni of this university. These two points make the two universities distinguished of all.

Compared to the United States, Forty-six Muslim majority countries, on the other hand, with 16 per cent of the world population, had only two, or 1 per cent of the universities ranked in the list. The two universities were from Malaysia, Universiti Kabangsaan and Universiti of Malaya. Without diminishing their achievement, the two universities were ranked as numbers 185 and 192 with overall scores of 29.2 and 28.6 respectively from a possible score of 100 . On the important measure of faculty citation, an indicator of intellectual creativity and impact, the two universities had the lowest scores. ${ }^{4}$ The University of Indonesia (UI), the best university of this country, was unfortunately ranked as number 250 in this category. ${ }^{5}$

Several factors can account for these conditions, the most important being the meager resources allocated by Muslim countries to research and development. On average, Muslim countries spend 0.45 per cent of GDP on research and development. The comparable figure for Organization for Economic Co-operation and Development countries is 2.3 per cent. These conditions are also a legacy of the colonialism experienced by most Muslim countries for an extended period in the past two centuries, during which they endured some of the worst excesses of racial and economic exploitation that stalled their development. But most of the causes of their present predicament can also be attributed to prevailing cultural and 
political practices. Other countries such as South Korea, Singapore, Taiwan and India have taken notable strides in the fields of science and technology and are among the leading emerging economies.

The non-availability of funds can hardly justify the absence of good universities in resource-rich countries such as Saudi Arabia and Kuwait, each of which are reportedly earning more than \$US 500 million daily from their oil exports alone. An encouraging development that appears to be taking place is that as academic and administrative conditions in the public sector universities have declined, the private sector has responded by establishing well-resourced universities. This is illustrated by the establishment of the Aga Khan Medical University and Lahore University of Management Sciences in Pakistan and Belkent University in Turkey. Pelita Harapan University in Indonesia might also be another example in this respect. This university is one of the youngest institutions for higher learning in Indonesia, but it is fast making a name for itself in the region.

\section{NATIONAL CONTEXT}

The report of the Times Higher Education Supplement (THES) in the end of 2006 about university ranking internationally (as already mentioned above) suggests that Indonesian universities may be a long way from establishing themselves as world class institutions on par with the best universities in The United States, Britain, Australia, Japan and Singapore. While the more established Indonesian universities such as University of Indonesia (UI), Gajah Mada University (UGM), and Bogor Agricultural Institute (IPB) are household names in the country and have a long tradition, over the past two decades new private universities have begun to mushroom, offering not just better facilities but a more all rounded and holistic curriculum.

Pelita Harapan and Bina Nusantara University, for example, have added a new dimension to higher education in the country by introducing international students and foreign faculty members. University of Pelita Harapan is the first university in Indonesia to have hired a foreign educator as its president. In setting out to rank the top 10 private and state universities in the country, Globe Asia developed a set of criteria which is comprehensive and takes into account both educational excellence and physical facilities as well as various strengths and weaknesses of each institutions.

At the national level, the GLOBE Asia has selected top 10 private and state Indonesia's best universities this year (2008). In formulating the ranking, the GLOBE Asia developed 10 criteria. Under Comprehensive 
University, the criteria was to be a full fledged university, the institution must have at least 30 different disciplines ranging across the spectrum of academia, and must have the faculty of Law, Medicine and Business. Apart from this, other key criteria to rank the universities include the quality of the faculty (qualification and experience) and the depth and extend of research. The universities were accorded high points particularly when they have a stand alone research institute. Also, internalisation under which the GLOBE looked the number of programs conducted in English, tie-ups with other universities, the number of international faculty and international students.

Another important criterion is campus life, in that, it must be attractive. Clean green and healthy environment promotes concentration and thus better academic performance among the students. This section also includes library facilities, sport and music facilities, range and quality of food found on campus as well as the standard of the student centre. Finally, the criteria of the top universities reflect the role universities play in society. This includes the influence a university has on society at large and the employability of its graduates.

Based on these criteria the GLOBE Asia selected the top ten state universities, ranging from the first to the tenth. These universities are University of Indonesia, Gajah Mada University, Bandung Institute of Technology, Bogor Institute of Agriculture, Padjajaran University, Airlangga University, Hasanuddin University, Surabaya Institute of Technology, Diponegoro University and University of North Sumatra. While the top ten private universities are Pelita Harapan University, Trisakti University, Tarumanagara University, Atmajaya University, Parahyangan University, Bina Nusantara University, Muhammadiyah Malang University, Maranatha University, Satya Wacana University and Petra University. ${ }^{6}$

Why did the GLOBE Asia classify the University of Indonesia as the Indonesia's top university? The University of Indonesia has the most reputable Economic faculty in the country and its alumni include current Finance Minister Sri Mulyani Indrawati and noted economist such as Chatib Basri, Faisal Basri and Syahrir. The university also has a strong reputation for its business and management programs and UI graduates seldom find it difficult to get jobs. This university is widely regarded as one of the best universities in the country, and is making a name for itself as a research institution. It scored higher than any other Indonesian institution of higher learning in the Times Higher Education Supplement (THES) World University Ranking for 2006, with the quality of research the main consideration. The University of Indonesia is now founded the directorate 
of research and community service. In 2007, UI allocated more than $\$ 1.1$ million for the research centre. This amount is doubled to $\$ 2.2$ million in 2008. To become a World Class in research, its lecturers should have high quality. While the government pays only $\$ 270$ a month per lecturer, UI adds $\$ 1000$ per month. This is a significant bonus to encourage the performance of its academics. ${ }^{7}$

In technology, the Bandung Institute of Technology (ITB) has no equals. Students vie to enter its departments of information sciences, mining, petroleum, geophysics and chemistry. The university graduated two of Indonesia's presidents: Sukarno and BJ Habibie. However, ITB's excellence in this area is overshadowed by Bandung's Parahyangan University and the Gajah Mada University (UGM) in Yogyakarta. UGM is also rated as the best in Indonesia for its Law Faculty. Also this university is well-known because of its reputation as a school for leading economists of the country.

The Bogor Agricultural institute (IPB) has no equals when it comes to agriculture, and it also recognized as the best school for veterinary studies. President Susilo Bambang Yudhoyono received his doctorate from this university just as he took control of the nation's affairs. Airlangga University of Surabaya is reputed to be the country's best in Nursing. The university continues to act as a pace-setter in the medical community, with its Tropical Disease Centre recognized as the best in Southeast Asia.

In terms of private university, Pelita Harapan University (UPH) ranks as our top private university in Indonesia mainly because of its comprehensiveness in terms of its degree programs, its research and development (R\&D) facilities, its holistic education, its international programs and tieups and its campus facilities which are the best in the country. Striving to become a world class university, the UPH provides a range of facilities for its students that are comparable to those world-class universities, such as Institute for Nanotechnology, a boon for students of medical faculty, a concert hall, a dormitory for 1300 students. There is also student lounge and sport facilities including a soccer field, basketball court, swimming pool and fitness centre. Finally, classrooms set a new standard in comfort.

The Pelita Harapan University aims to be one of the best university in the Asia-Pacific region. To achieve this goal, the university has already been cooperating with the best universities overseas. The joint cooperation programs include a dual degree program with Queensland University of Technology in Australia and other deals with Melbourne University. There are also programs with universities in The United States and Asia, including the National University of Singapore. This university wants to 
convey to the world that it wants to open the doors wider for the world's best practices to stream into Indonesia, particularly from America, Australia and Europe so that students can get a world class education without leaving the country. The university also strives to increase the number of overseas students. Currently, there are 100 overseas students out of 9000 of the total students. It is also very keen in terms of the quality of lecturers. This is gauged by the number of foreign lecturers who teach at the university. The lecturers should hold a masters degree from overseas and have professional experience. ${ }^{8}$

The description of eminent universities above suggests that university level is judged based on academic greatness, including program comprehensiveness (over 30 academies and having Faculty of Medicine, Law, and Business School), faculty quality (student-teacher ratio and foreign faculty members), academics and research (dedicated centre and program, copy right and patents, and international journal citation), internalization (program in English, international programs, international faculty, and international students).

Another judgment of university level is the extent to which its program is holistic and whether or not the campus life is dynamic. This includes holistic education (having sport, art and music program), residence and dorm facilities (quantity capacity and facilities and quality) campus life and activities (student organizations, student programs, and student environment, campus facilities (green concept and modernity, library facilities, sport facilities, music facilities, art facilities, food facilities, and student centre). Finally, university is ranked based on its impact to society, including its influence on society, employability of its alumni, legacy and history.

It is very unfortunate that only a small number of universities in Indonesia fulfill or close to the above criteria. According to Yahya Muhaimin, the former Minister of National Education, Indonesian national education faces at least three major educational problems. This includes widespread inequitable access to education, low quality and relevance, and weak educational management. Apart from these major issues, most academic staff members lack scientific and technological excellence and independence. Educational disparity can also be witnessed across geographical areas, urban and rural, between western and eastern parts of Indonesia. ${ }^{9}$ These issues should be seriously taken into consideration in enhancing the quality of education in Indonesia.

\section{DISCUSSION}

A new paradigm of the function of higher education in society has

emerged over the last twenty years. While universities still maintain their 
role as the conscience of society, more pragmatic roles have been evolving over time: universities no longer pursue knowledge for its own sake, rather they provide qualified manpower and produce knowledge. With this new economically oriented paradigm, accountability becomes an important aspect, as higher education will be judged in terms of outputs and the contributions it makes to national development. ${ }^{10}$

Criteria to assess the quality of the work and of the teams which carry out research in universities today should be differ from those of more traditional, disciplinary science. In the past, quality was determined through peer review. Control was maintained by careful selection of those judged competent to act as peers, which was in part determined by their previous contributions to their discipline. Today, with the new paradigm, additional criteria should be added through the context of application which now incorporates a diverse range of intellectual interests as well as other social, economic or political ones. ${ }^{11}$

Quality assurance will be more complex as universities move to broaden the range of their knowledge missions. Until now, quality control in teaching and research has been exercised through essentially the same type of peer review system. Quality has been a matter for academics. It has been up to them to determine when quality in both teaching and research has been achieved. Hybridization of the disciplinary structure is likely to continue to be the main mode of expansion in teaching provision in the future. If new research practices diffuse more widely throughout universities, entire new assurance mechanisms will be necessary for the problemoriented teaching that will accompany it. Hence, one can expect to see the development of new benchmarking methodologies and the production of a range of benchmarking studies across the higher education sector. ${ }^{12}$

In the quality assurance processes which are now emerging, a much wider range of factors should be under consideration. Universities will not be able to insist on criteria which reflect their intellectual interests alone rather they will be one actor among several and the challenge for them will be to ensure that their legitimate interests survive the negotiation process.

Another important aspect to consider with the new paradigm of Indonesian higher education learning is that a university in Indonesia carries out certain functions in society: education, research and community service. The society as the source of university funding, has the right to be informed on the quality of university's performance. In order to provide objective information to the society, the National Accreditation Board of Higher Education (BAN-PT) was established. The accreditation process should not be limited to activities carried out by the BAN-PT conceptually. 
Accreditation could also include benchmarking carried out by other national and international agencies, such as certification by professional associations. In addition to the external evaluation through accreditation, a widely accepted good practice in management is decision making based on facts, data, and information that are gathered then processed and presented through an evaluation process. ${ }^{13}$

Quality, autonomy, accountability, accreditation, and evaluation, present the five pillars of the new paradigm in higher education management. In this respect, different implementation schemes are required for each level of management hierarchy, such as the central authority (Directorate General of Higher Education), universities, academic units within each institution, and individuals. The process of implementing the concept includes granting an opportunity to the smallest unit to develop its own plan, implement the plan, and be responsible as well as accountable for that. Similar concepts have been implemented in the United Kingdom, Australia, New Zealand, and Canada. The most important feature of its implementation is the decentralization of management control away from the central authority to the individual institution.

This is what the writer thinks an important procedure to prepare the universities in becoming a credible moral force. Competition is an acknowledged central force in higher education and nurtured by many scholars. To be competitive both in the national and international level, the provision of educational services should be made contestable. It provides an opportunity for the beneficiaries not to be uniform, and relies mostly to the ability to participate within a predetermined corridor.

\section{END REMARKS}

In conclusion, quality, autonomy, accountability and accreditation are important factor to enable university to compete both nationally and internationally. The relinquishing of certain portions of authority from central to local government should bring with the university the necessary spirit of resilience for global competition. This means that local government and community will be more highly motivated to develop the university. It is in this context that quality education will make its significant contribution to the competitiveness of our human resources. The quality is meant not only to fulfill national standards, but also to meet international standards, so that Indonesian people are able to compete with people from other nations. 


\section{END NOTES:}

1. See "The Best Investment Money can Buy", Globe Asia: Top Guide to 10+10 Indonesian Universities, $1^{\text {st }}$ Annual Issue, 2008, p. 14.

2. See Globe Asia, p. 14, and Journal of Higher Education Policy and Management, Vol. 25, No. 2, November 2003, pp. 161-172.

3. Riaz Hassan, "Islamic Thought in Limbo", The Australian, 19th Edition, December 2006, p. 3-4.

4. Ibid.,

5. Lihat Kompas edisi 14, November 2004.

6. See Globe Asia, 2008, pp. 13-15.

7. See "University of Indonesia, Indonesia's Top University: Truly comprehensive; strong in research; exerts wide influence", Globe Asia, 2008. pp. 24-27.

8. See "Pelita Harapan University: Global Campus for Indonesia", 2008, pp. 18-23.

9. Fasli Jalal dan Baharuddin Musthafa (eds.), Education Reform in the Context of Regional Autonomy: the Case of Indonesia, Jakarta, Ministry of National Education, 2003, p. xiii.

10. Satryo Soemantri Brodjonegoro, Higher Education in Developing Countries: Peril and Promise, http://www.tfh.net/resources/satryo_soemantri_brodjonegoro2.htm, 13-09-2006, 04. pm., pp. 1-10.

11. Bill Guerin, "Indonesia behind the learning curve", Asia Times, August 30, 2006, pp. 6-9.

12. Mark Sinclair, "Three Futures for University Provision: The Social Justice Market, State Capitalism, and Private for-Profit University", Journal of Higher Education Policy and Management, Vol. 25, No. 2, November 2003, pp. 161-172.

13. UNDP, "Towards a New Consensus: Democracy and Human Development in Indonesia", Indonesia Human Development Report 2005, October 2005, pp. $132-$ 156.

\section{BIBLIOGHRAPHY:}

Alexander, FK., "The Changing Face of Accountability: Monitoring and Assessing Institutional Performance", Journal of Higher Education, Vol. 71, No. 4, 2005, pp. 441-431.

Brodjonegoro, SS., Higher Education in Developing Countries: Peril and Promise, http://www.tfh.net/resources/satryo_soemantri_brodjonegoro2.htm, 1309-2006, 04.pm.

Chipman, L., "Globalisation and the Higher Education Providers of the 21st Century", Paper presented to the Australian Association for Institutional Research 12th Annual Conference, Queensland, 3-5 September 2003.

Dubrin, A. J., Leadership: The Complete IDEAL'S GUIDES, Jakarta, Prenada, 2000.

Fadhil, K., Kompas edisi 14, November 2004.

Gale, T., and McNamee, P., Just Out of Reach: Access to Equity in Higher Education, Australian Universities Review, Vol. 37, No. 2, 2002, pp. 8-12.

Guerin, B., "Indonesia behind the learning curve”, Asia Times, August 30, 2006, pp. 6-9.

Hassan, R., "Islamic Thought in Limbo", The Australian, 19 th Edition, December 2006, pp. 3-4. 
Indrajit, R.E. dan Djokopranoto, R., Manajemen Perguruan Tinggi Modern, Yogyakarta, ANDI, 2006.

Jalal, F. and Musthafa B., (eds.), Education Reform in the Context of Regional Autonomy: the Case of Indonesia, Jakarta, Ministry of National Education, 2003.

Michael, S., "Higher Education Institutional Collaborations", Journal of Higher Education Policy and Management, Vol. 25, No. 2, November 2003, pp. 130-146.

Sinclair, M., "Three Futures for University Provision: The Social Justice Market, State Capitalism, and Private for-Profit University", Journal of Higher Education Policy and Management, Vol. 25, No. 2, November 2003, pp. 161-172.

Tilaar, HAR, Manajemen Pendidikan Nasional: Kajian Pendidikan Masa Depan, Bandung, Rosdakarya, 2006.

Tjiptono, F., and Diana, A., Total Quality Management, Yogyakarta, ANDI, 2003

Turney, C. and Hatton, N., The School Manager: Educational Management Roles and Tasks, Sydney, ALLEN \& UNWIN, 2001.

UNDP, "Towards a New Consensus: Democracy and Human Development in Indonesia", Indonesia Human Development Report 2005, October 2005, pp. $132-$ 156.

Zainuddin, SK., "The Best Investment Money can Buy", Globe Asia: Top Guide to 10+10 Indonesian Universities, $1^{\text {st }}$ Annual Issue, 2008. pp. 13-17. 